\title{
Towards sustainable public FM: collective building of capabilities
}

\author{
Ramskov Galamba, Kirsten; Nielsen, Susanne Balslev
}

Published in:

Facilities

Link to article, DOI:

10.1108/F-05-2013-0039

Publication date:

2016

Document Version

Publisher's PDF, also known as Version of record

Link back to DTU Orbit

Citation (APA):

Ramskov Galamba, K., \& Nielsen, S. B. (2016). Towards sustainable public FM: collective building of capabilities. Facilities, 34(3/4), 177-195. https://doi.org/10.1108/F-05-2013-0039

\section{General rights}

Copyright and moral rights for the publications made accessible in the public portal are retained by the authors and/or other copyright owners and it is a condition of accessing publications that users recognise and abide by the legal requirements associated with these rights.

- Users may download and print one copy of any publication from the public portal for the purpose of private study or research.

- You may not further distribute the material or use it for any profit-making activity or commercial gain

- You may freely distribute the URL identifying the publication in the public portal

If you believe that this document breaches copyright please contact us providing details, and we will remove access to the work immediately and investigate your claim 


\section{@ \\ Emerald Insight}

\section{Facilities}

Towards sustainable public FM: collective building of capabilities

Kirsten Ramskov Galamba Susanne Balslev Nielsen

\section{Article information:}

To cite this document:

Kirsten Ramskov Galamba Susanne Balslev Nielsen , (2016),"Towards sustainable public FM:

collective building of capabilities", Facilities, Vol. 34 Iss 3/4 pp. 177 - 195

Permanent link to this document:

http://dx.doi.org/10.1108/F-05-2013-0039

Downloaded on: 11 May 2016, At: 07:22 (PT)

References: this document contains references to 46 other documents.

The fulltext of this document has been downloaded 25 times since $2016 *$

Access to this document was granted through an Emerald subscription provided by All users group

\section{For Authors}

If you would like to write for this, or any other Emerald publication, then please use our Emerald for Authors service information about how to choose which publication to write for and submission guidelines are available for all. Please visit www. emeraldinsight.com/ authors for more information.

\section{About Emerald www.emeraldinsight.com}

Emerald is a global publisher linking research and practice to the benefit of society. The company manages a portfolio of more than 290 journals and over 2,350 books and book series volumes, as well as providing an extensive range of online products and additional customer resources and services.

Emerald is both COUNTER 4 and TRANSFER compliant. The organization is a partner of the Committee on Publication Ethics (COPE) and also works with Portico and the LOCKSS initiative for digital archive preservation.

*Related content and download information correct at time of download. 


\title{
Towards sustainable public FM: collective building of capabilities
}

Kirsten Ramskov Galamba

The Capital Region of Denmark, Copenhagen, Denmark, and

Susanne Balslev Nielsen

Centre for Facilities Management, Department of Management Engineering, Technical University of Denmark, Kongens Lyngby, Denmark

\begin{abstract}
Purpose - Public facilities management (FM) is in the unique position of aligning building projects and FM with the policies of sustainable development at societal level. However, sustainable facilities management (SFM) is an emergent profession, and there is a need to build a code of conduct for SFM in FM organisations. The purpose is to develop and test a workshop based concept for collective building of capabilities targeting in-house FM organisations, in particular public in-house FM organisations.

Design/methodology/approach - This research explores the role of public facilities managers and examines how an empowerment process can help FM employees develop collective competences for SFM. The methodologies used are literature review, and a 3-year-long action research process in the Danish local authority, Albertslund, which is internationally recognised for its innovative and green profile.
\end{abstract}

Findings - This paper describes the phenomenon of public SFM imbedded in societal steering paradigms and suggests a framework for a sustainable FM code of conduct. The suggested "Next generation SFM code of conduct" support the employees in taking a proactive strategic position in which translation between politics, strategy, tactics and daily practice becomes the basis for prioritisation and decision-making. The capabilities needed is FM knowledge (including FM know-how, understanding of technologies for sustainability and public governance); it is the FM code of conduct, and it is control of own practice to be obtained through strategies and planning, collaboration and education.

Research limitations/implications - This study is based on findings in a single local authority, why the findings are primary valid for concept development to be further developed and tested. However, the local authority of Albertslund is recognised as a front runner in green FM, why this case, compare to other cases, represents a relatively mature thinking in terms of FM contribution to sustainability at societal level. When this FM organisation express a need for developing collective

(C) Kirsten Ramskov Galamba and Susanne Balslev Nielsen. Published by Emerald Group Publishing Limited. This article is published under the Creative Commons Attribution (CCBY 3.0) licence. Anyone may reproduce, distribute, translate and create derivative works of this article (for both commercial and non-commercial purposes), subject to full attribution to the original publication and authors. The full terms of this licence may be seen at http://creativecommons.org/ licences/by/3.0/legalcode

The authors would like to thank leaders and employees from the Danish local authority of Albertslund for sharing openly their reflections on sustainability and the connection to everyday tasks. The authors would also like to thank Centre for Facilities Management - Realdania Research for the founding which made this research possible, and finally the authors would like to thank our FM-colleagues at DTU and RUC, in DFM, in NordicFM and in EuroFM, for discussions which inspired academic discussions on the emerging discipline of SFM.

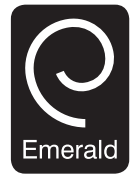


competences for sustainability in FM, it can be assumed that less mature FM organisations needs it even more. The findings seem relevant beyond public FM organisations.

Practical implications - The produced framework for a sustainable FM code of conduct is useful for educational purposes as well as for strategic decision about FM organisations collective competence profile. The use of workshops for the building of collective competences might be useful for many other organisations and not only public FM organisations.

Social implications - Public FM organisations manage significant shares of existing buildings and can be a driver for societal change if they have the capabilities. This paper provides an answer to how these collective capabilities can be build within an organisational development process, through dialogue and collective reflections.

Originality/value - This paper is a pioneer in understanding the capabilities needed in FM organisations to take leadership in an integration of sustainability in FM processes.

Keywords Action research, Education, Facilities management, Organizational development, Management, Professionalisation, Sustainability, Employees, Code of conduct, Public buildings, Green FM

Paper type Research paper

\section{Introduction}

Sustainability in the built environment has been on the political and professional agenda for decades, and a variety of definitions and approaches to sustainable development have emerged over time. Within the field of facilities management (FM), sustainability has been addressed in the academic literature (Baharum and Pitt, 2009; Love and Bullen, 2009; Elmualim et al., 2010; Price et al., 2011; Junghans, 2013) as two distinct challenges: either as a challenge to implement sustainable buildings, green technology, audited management systems and sustainability certifications or as a challenge to integrate sustainability into the local FM culture and work processes (Elmualim et al., 2010; Galamba, 2011a). This paper adds to the existing body of literature by exploring a framework for FM organisations' collective capabilities for strategic sustainable facilities management (SFM).

FM has the potential to play an important role in relation to an organisation's environmental and social profile, as buildings and their operation and maintenance cost a great deal in energy and material consumption and can have a significant effect on the health and well-being of building users, including operators and service personnel. FM in the public sector, or public FM, also influences the social aspects of sustainability at a local level; for example, the openness and accessibility of facilities to the general public are important for social coherence.

However, it can be difficult for a facilities manager to make decisions on a daily basis in accordance with a vision of sustainability, especially if that vision is unclear. In a complex world, green accounting and sustainability certifications provide important guidelines, but they cannot be the only frameworks for sustainable action because the various aspects of sustainability (e.g. social, environmental and economic aspects) must be regarded as interconnected. The rapidly changing world and the complexity of the FM task call for reflective practitioners who are able to navigate a work life rife with contradictions and dilemmas and who can determine the appropriate course of action at the appropriate time. In this article, we suggest that individual and collective capabilities for sustainable FM practices must be purposively accumulated, which can be achieved through a workshop-based process in which employees construct common 
utopian horizons for a sustainable society and a culturally embedded FM code of conduct.

This article provides new insights into the professionalisation of a public FM organisation through an action research process and suggests that a collective learning process that is facilitated primarily through workshops can help FM organisations develop collective capabilities to make a purposive impact on sustainable development. The impact perspective is especially relevant at the local level but is also relevant at the societal level, as public FM is a potential driver of green markets, green innovation and welfare as well as a major resource consumer. Following this introduction is a description of the research methodology and the theoretical framing of sustainable FM. As in Fennimore (2013), SFM is viewed as "a quest rather than an absolute. It is a goal that we, as facilities managers, could be striving towards for the good of the planet". The workshop process is focused on translating this "goal" into a collective understanding that can guide the daily practices of employees as well as the short- and long-term development goals of the organisation. The goal is not only to produce facilities and services that place the least constraints on local and global ecosystems but also to contribute to a long-term societal transition. A deductive research approach using Fournier's (1999) theory on the "process of professionalisation" is used to unfold the individual and collective competences required for a sustainable FM conduct in an in-house FM organisation such as the local authority of Albertslund. The developed framework is of practical relevance for leaders of internal FM organisations who face the challenge of integrating sustainability into local FM culture and work processes. It is also relevant to FM consultants giving advice on organisational matters such as reorganisation or establishment of an internal FM centre with SFM in its mission. Because the paper stresses the professionalisation of FM, the findings are equally relevant for educators within FM educational programs whose aim is to develop competencies for strategic SFM; a holistic understanding of sustainability supports reflexive FM practices beyond the instrumental implementation of managements systems, certifications and key performance indicators (KPIs).

\section{Methodology}

The methodological approach included a literature review and action research undertaken at the local Department of Public Property in Albertslund, Denmark, from 2008 to 2011. The local authority of Albertslund has a high profile in its actions implementing Agenda 21 and environmental sustainability and, as such, is a trendsetter in integrating sustainability into Danish public real estate management. Albertslund has published green accounts for the municipality since 2000, and in 2007, it became the first local authority in Europe to become 100 per cent certified according to the European "Eco-Management and Audit Scheme". The local authority is at the forefront of the implementation of sustainability tools in Denmark (Nielsen and Galamba, 2010; Galamba, 2011a, 2011b). The conclusions of this research are therefore relevant both to local authorities in general and to larger private organisations whose FM departments confront the challenge of choosing a strategy for sustainability and committing to building in-house capabilities to implement such a strategy.

The process was inspired by critical utopian action research (Svensson and Nielsen, 2006), and the relational paradigm (Lerborg, 2010) was based on appreciative inquiry (Cooperrider and Srivastva, 1987) and systemic thinking (Flood, 2010). The workshop 
method played an important role in the action research process: the researchers hosted eight full workshop days for the entire department (27 employees) and 11 workshops with subgroups over a three-year period from 2009 to 2011 (Galamba, 2011a). Semistructured interviews with key persons in the FM organisation were also conducted, to enable the researchers and key persons to collective reflect on the status of the organisational learning process and to plan the upcoming workshops. Each interview lasted about one hour and had a list of questions as starting point, while also allowing the informants to contribute with other issues. The empirical data include transcriptions of 11 interviews.

The research strategy is a longitudinal study (three years) of action research in Albertslund to facilitate an organisational learning approach to improve capabilities for strategic SFM and to explore the employee perspective on what it takes to work holistically and strategically with SFM. The Albertslund department was organised into four teams: architecture and planning, building and maintenance, geographical information system (GIS) and call centre and roads and parks. For this reason, the chosen focus was on informants at the departmental and team levels in the workshop process, and interviews with key informants were used to reflect on the process and to conceptualise subsequent workshops. For a more comprehensive presentation and analysis of the action research process, see the $\mathrm{PhD}$ thesis by Galamba (2011a).

This article reports the construction of a SFM capability framework as a result of a deductive research process conducted as an extension of the $\mathrm{PhD}$ project to improve the initial analysis of the empirical data collected through the multi-method qualitative study (workshops and interviews), which is documented in logbooks, sound recordings and interview transcriptions. Figure 1 illustrates the research approach.

The findings from the deductive research process are validated by a survey conducted in September 2014. The workshop participants were once again asked to share their views on the effect of the action research process this time retrospectively (two years later). Of the 27 employees, 20 who participated in the full process were still employed by the local authority in May 2014, and of those remaining employees, we received replies from nine individuals (response rate 45 per cent).

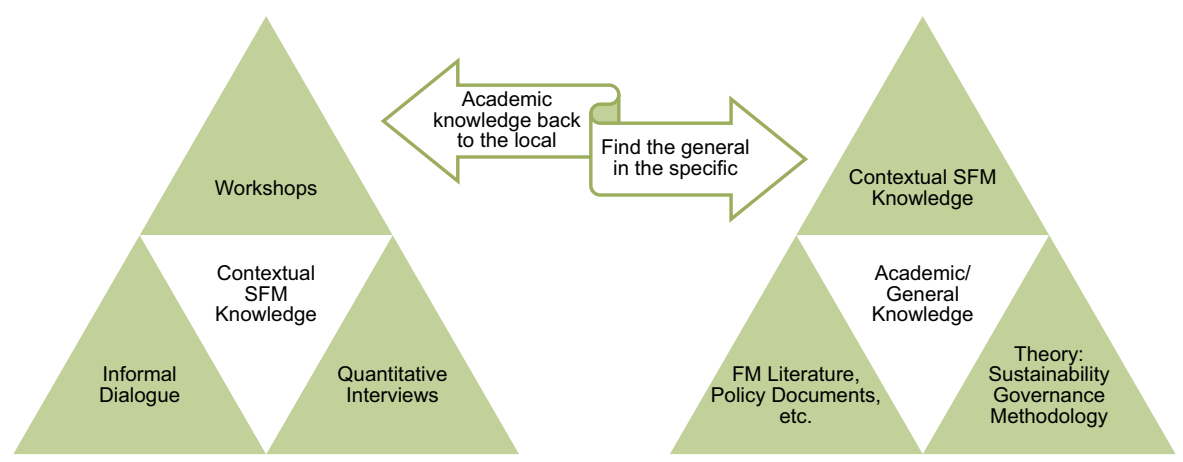

Figure 1.

Contextual and general knowledge
Notes: Contextual knowledge of SFM is created on the basis of learning from workshops, interviews and informal dialogues; academic and more general knowledge is created in the discussion of contextual knowledge, relevant theory and studies of FM 
One potential weakness of this research is that it is an in-depth study of only one authority; however, the time-consuming process did not allow for comparative studies. Rather, these research findings have been validated by capturing a situation representatives from other Danish public FM organisations identified as common to Danish public FM organisations. The case selection strategy is primarily information based.

From a philosophy of science perspective (Saunders et al., 2012), the process in Albertslund can be viewed as an experiment facilitating an organisation's collective reflections on the concept of sustainability and the concept's translation to the local organisational context and individual work. Through this experiment, we study the joint reflections of researchers and practitioners to develop a characterisation of the phenomenon of public SFM and, specifically, the building of joint capabilities. This study draws on primary literature (Fournier, 1999) as well as the literature on societal strategies for sustainability, sustainable FM and dominant trends in public governance to inform and frame the workshop process. The literature review is presented below.

\section{Facilities management as a modern professionalised area}

The first group of studies to be discussed addresses the work-life perspective of FM and presents FM practices in the context of general public administration trends.

These articles consider public FM to be a societal phenomenon connected to the overall shift in the paradigm of governance from bureaucracy to new public management (NPM) (Brignall and Modell, 2000; Hood and Peters, 2004) and the more soft, relational form of governance described as the relational paradigm (Lerborg, 2010). Public FM developed in the 1980s with the implementation of NPM, which adopted a market-based approach to public governance (Wiggins, 2010).

NPM was viewed as an answer to the strong critique of the welfare state as bureaucratic, hierarchical and often unresponsive to the needs and differences of individuals and communities. Within NPM, professional silos were also challenged with a critique of professions and expertise. Professions were described as unaccountable systems of exclusion delegitimising local and alternative forms of knowledge and depriving the population of its existing capacities and local knowledge. Mitchel Dean presents the notion of "technologies of performance" as technologies of government designed to penetrate the enclosures of expertise and to change professional domains into new formal calculative regimes:

Devolution of budgets, setting of performance indicators, "benchmarking", the establishment of "quasi markets" in expertise and service provision, the "corporatisation" and "privatisation" of formerly public services and the contracting-out of services are all more or less technical means for locking the moral and political requirements of the shaping of conduct into the optimisation of performance (Dean, 1999).

The claim is relevant in an FM context characterised by governance technologies, with the notion of "agreed services" in the European definition and emphasis on contracts, service level agreements and KPIs (Jensen, 2011).

Fournier terms this process a "process of professionalisation" in which the need for control in a flexible work organisation is resolved by mobilising the "autonomy" of individual employees through the alignment of their self-governing and self-actualising propensities with the competitive advancement of the organisation. He claims that individual employees must translate politics and more or less explicit criteria of

\section{Collective building of capabilities}


$\mathrm{F}$

$34,3 / 4$

182

legitimacy into practice based on control of their own practices and body of knowledge (Fournier, 1999) (Figure 2). The mechanism described by Fournier incorporates actions into a management framework that is designed to ensure transparency. Leaving employees to decide which actions may be appropriate requires a high degree of discipline on the part of management. Quality management is a means of control related to FM (Jensen, 2011).

Fournier distinguishes between having a "profession" and being "professionalised" in that the latter allows for disciplines without a formal educational background to be included (Fournier, 2008). The critical factor in the concept of professionalisation as defined by Fournier raises the question of whether a profession can be loyal to a professional code of conduct and safeguard the expertise and standards of the profession while consistently meeting the needs of individual clients. Tay and Ooi appear to believe in this possibility; they formulate the following criterion for the profession: "Expertise and standards of the FM profession derive from meeting the needs of individual clients" (Tay and Ooi, 2001).

Jensen (2011) notes that FM has the character of a professional area, although neither its specialised knowledge nor its methods are sufficiently coherent to constitute a profession. According to Jensen, a professional area emerges when a community is created with the aim of defining the profession and ensuring it through institutionalisation. To build a profession requires purposive action, as professions do not simply emerge spontaneously as a result of technological or structural changes in society. Formal educational qualifications and institutionalisation through associations are important steps that have been taken in FM: IFMA and EuroFM are important international associations, as is DFM in the Danish context. Furthermore, FM has gradually emerged as an academic discipline (Jensen, 2011).

Grimshaw (2001) adds to the discussion that the essence of a profession is its significance in terms of public purpose, intellectual traditions and a relationship of trust. A profession is trusted to handle important areas of policy and practice for the public and therefore comes to be regarded as an authoritative symbol of social responsibility. Claiming to be a profession thus implies that ethical issues have been considered in relation to the manner in which professionals conduct themselves (Grimshaw, 2001). One question concerning FM ethics, however, is whether such ethics should be developed by business or by professional bodies. That FM ethics cannot be viewed in isolation from the development of business ethics indicates the possibility of conflicts between business codes and a professional code of conduct for FM.

Figure 3 depicts how translation occurs between policy and the personal conduct of the facilities manager through the articulation of the criteria of legitimacy. As suggested

Figure 2.

Translation occurs between policy and the personal conduct of the facilities manager through the articulation of criteria of legitimacy.

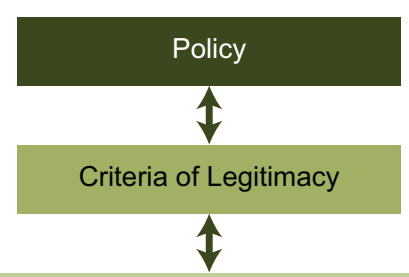

Facilities Managers' Personal Conduct 
by Fournier, the conduct of the facilities manager is thus based on the body of knowledge and control of his or her own practices (Fournier, 1999), which should be supported by a specific code of conduct, including ethical codes as suggested by Grimshaw (2001).

This general framework for understanding the facilities manager's capabilities is the theoretical framework that we develop further on the basis of the empirical data from the Department of Property and Roads in the Danish Municipality of Albertslund. First, however, an introduction to the emerging field of public FM and societal strategies for sustainability is necessary to connect the ongoing changes in Danish public FM organisations with governance paradigms for implementing strategic leadership for sustainability in FM.

\section{The emergence of public facilities management}

The international academic literature on FM in public organisations remains limited (Baharum and Pitt, 2009; Nielsen and Galamba, 2010), and the extent of the need to distinguish between public FM and FM in for-profit organisations is debatable, as many FM tasks are identical regardless of the environment. As public organisations, however, public FM departments must align with public policies, regulations and ethical codes within public administrations, which indicates the value of addressing public FM as a specialty within FM. FM in the public sector can affect the social aspects of sustainability at a local level because the openness and accessibility of facilities to the public are important for social coherence. However, even public FM is not a fixed phenomenon but is rather an emerging sub-discipline within FM. The following is a brief introduction to the evolution of public FM in Denmark, which we regard as fairly similar to its development internationally, with the exception of some countries with a longer history of public FM (Jensen and Malmstrøm, 2012).

FM was introduced to local authorities in Denmark during the 2007 structural reform of the public sector, in which a critical period of centralisation occurred. According to Jensen and Due, responsibility was so decentralised that many local authorities had no oversight of their properties and no common procedures for managing their facilities. The organisation of FM-related activities was the result of history rather than of strategic choice, and many employees who were responsible for FM were not properly qualified to handle real estate management and FM-related activities (Jensen and Due,

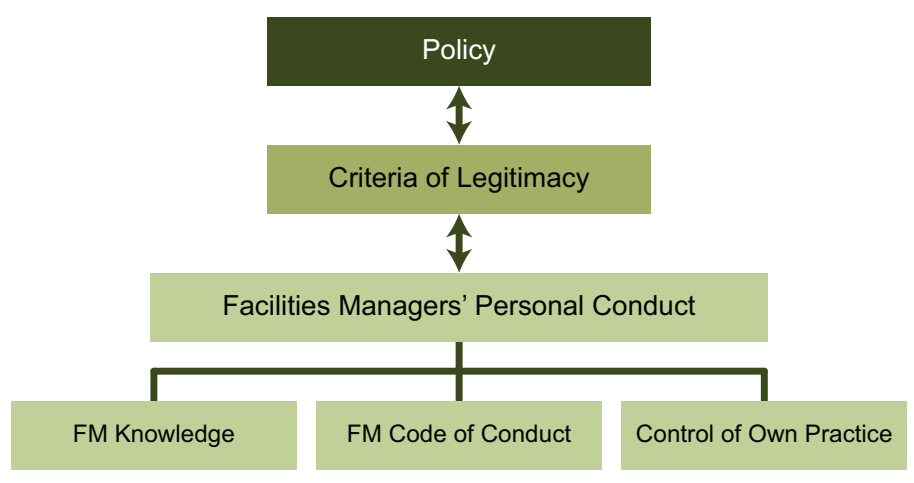

Figure 3. Translation occurs between policy and the personal conduct of the facilities manager through the articulation of criteria of legitimacy.

The conduct of the facilities manager must be based on a body of FM knowledge, an FM code of conduct and control of his or her own practice 
2008). It was believed that a paradigm shift in the approach to public real estate was necessary: rather than viewing public property largely as an expense, the real estate portfolio should be regarded a strategic asset that could facilitate the overall visions and goals of the local authority.

According to Due (2007), the most important prerequisite for FM is an alignment with political intentions and customer needs, both in the present and in the future. In practice, this process occurs by establishing targets and by specifying KPIs with the involvement of employees as well as by joint articulation of criteria for legitimacy that "binds" employees to a framework of obligations that include flexibility, efficiency and service-mindedness. In a public organisation that emphasises NPM as its governance ideology, a management framework of contracting, target-setting, output measurement and bottom-line thinking constitutes the basis for action. In a public institution that emphasises values as the means of governance facilitated by mutual communication, the criteria of legitimacy become less obvious, and a deeper understanding of policy and managerial values is needed for employees to act in an appropriate manner. In both cases, however, the actions of employees are motivated by their desire to satisfy the criteria of legitimacy, regardless of what those criteria may entail.

After having outlined our understanding of public FM, we next present an introduction to some of the dominant societal strategies for sustainable development. This theoretical background on sustainable public FM informed the process in Albertslund and guides our understanding of megatrends in SFM.

\section{Societal strategies for sustainability}

Although sustainability has been on the political and professional agenda for decades, the latest IPCC report (IPPC, 2013) confirms that current strategies for sustainability are insufficient to break the pattern of unsustainable global development practices. Nature is exploited beyond the limits of regeneration, which is followed by the social erosion of local communities (Shiva, 2005; Nielsen and Nielsen, 2006; Sachs, 2007; Elling, 2010). Unsustainable patterns are also observed in connection with the organisation of work in both developed and developing countries. An increasing number of people in modern work organisations experience problems with stress and confront difficulties in their work-life balance, which should be viewed as an additional societal challenge related to the social aspects of sustainability (Sennett, 1999; Hvid, 2006; Nielsen et al., 2007). Hence, the challenge is to create a sustainable transition for society that embraces both social and environmental aspects and allows for a dignified life and balance with nature.

The severely negative environmental and social consequences of modernisation have led sociologists to reflect on how to understand and handle these new challenges. This problem was articulated in the 1980s by Ulrich Beck, who placed the concept of risk at the centre of his analysis of society (Beck, 1996), ranking the ecological crisis among the most pressing societal problems. The notion of reflexive modernity, referring to the constant examining and reshaping of social practice in light of new information (Mol, 1996), came to characterise modern society. This notion also influenced the construction of theory in the social sciences; ecological modernisation theory even spoke of "modernising modernity". The institutionalised destruction of nature was understood as a "structural design fault of modernity" that needed to be "repaired" (Mol, 1996). The assumption was that modern society had the capacity to establish self-correcting standards and technological solutions to societal environmental 
problems without making any major changes to consumption patterns and production (Holm, 2007).

Strategies associated with this approach are included in what is often referred to as "sustainable development", a term that was introduced in the report "Our Common Future" from the Brundtland Commission in 1987 (United Nations, 1987). The concept of sustainability was broadened from a narrow focus on environmental issues to embrace social and economic aspects of society as well. The linking of sustainability to "development", however, rendered the term rather ambivalent because it aimed at both sustainability and growth (as opposed to speaking of "limits to growth") and can be viewed as a de-radicalisation of the term "sustainability". The Brundtland report was followed by the UN Conference on Environment and Development (1992 in Rio), at which 178 countries signed the global action plan Agenda 21 (United Nations Department of Public Information, 1993). For the first time, Agenda 21 pointed to the important role of local authorities in ensuring sustainability (Holm, 2007). The notion of democracy appears in Chapter 28 of Local Agenda 21, which emphasises that citizens must participate in the creation of sustainable development (United Nations Department of Public Information, 1993).

Lovins et al. (2007) outlined a "roadmap for sustainability" based on their concept of natural capitalism (Hawken et al., 2010), which is an approach to sustainable development with the explicit double aim of protecting the biosphere and improving business profits and competitiveness. Natural capitalism is based on the concept of environmental economic analysis, which considers the market to be incomplete because it lacks mechanisms to include economies beyond capital. The claim is that environmental problems emerge because the value of nature is underestimated when economic decisions are made. Pollution is regarded as a "free" externality. The field of environmental economics aims to correct this market failure by "internalising" the external environmental effects in a process by which nature is given a price value in the capitalist market to enable regulation through the principle of "willingness to pay" (Nielsen and Nielsen, 2006).

Natural capitalism is based on whole systems thinking inspired by the work of Ludwig von Bertalanffy, who formulated general system theory (Dubrovsky, 2004). In the field of organisational analysis, the organisation is regarded as a complex system composed of interrelated parts that can be studied as an emergent whole. The organisation is open to its environment, and management action is taken to ensure that the organisation maintains a steady state using management functions that control activities and information within the organisation (Flood, 2006). Thus, according to the principle of natural capitalism, rather than focusing on parts of the system, phenomena are to be understood as emergent properties of an interrelated whole. An emergent property as a whole is said to arise when a phenomenon cannot be fully understood in terms of the properties of its constituent parts (Flood, 2006). Hence, when production is planned and implemented, it must be regarded as interconnected with the extraction of raw materials from nature, their transportation and refining and, at the other end of the process, the use and disposal of the resulting products. Natural capitalism emphasises that no waste must occur. Processes must be optimised in a way that allows the full use of raw materials to be assessed from a whole systems perspective, including the final disposal of products (Hawken et al., 2010). 


\section{First-generation public sustainable facilities management}

In a study of current conceptions of sustainable FM (Nielsen, 2011), three strategic approaches were identified as solutions to future problems:

(1) incremental approaches: limiting the environmental impact of organisational activities;

(2) radical approaches: acting from a vision of sustainable building; and

(3) transformative approaches: acting from a vision of a sustainable society and extending beyond the organisation to establish new partnerships for the co-creation of new socio-technical services and technologies.

The results of the study emphasised a tight connection between the organisational context and the FM approach to sustainability. The goal of the incremental strategy is to achieve a relative or absolute reduction in $\mathrm{CO}_{2}$ emissions, for example, and green accounting is an important tool here. Variations can occur in the choice of indicators; $\mathrm{CO}_{2}$ and energy use are typically included, but broader sets of sustainability indicators can also be used. The radical strategic approach aims to comply with the vision of a fully sustainable building. The strategy focuses on both the environmental and social aspects of sustainability and thus promotes environmentally sound behaviour by building users. In this strategy, the focus is on solutions related to the local community, and sustainability certifications such as LEED and BREAM are used as means of branding. Those who apply the transformative strategy focus on the development of new partnerships for the co-creation of new socio-technical services and technologies (Nielsen, 2011).

Although natural capitalism does not provide answers to problems of structural changes in society, it does serve as an ideology and a pragmatic position for businesses and should be regarded as one important strategy. However, society must develop some means of incorporating all substantial aspects of sustainability if we are to avoid complete relativism and social constructions as well as the risk of green-washing products and businesses. Our critique of this first generation of SFM - an umbrella for everything related to sustainability and FM - is that the societal transformation process is much more complex and encounters dilemmas that call for FM professionals who can translate a political agenda into strategic FM and can enable a translation between strategy and everyday tasks at the intersection of politicians, end users and colleagues.

Thus, in the next section of this article, the empirical findings from the action research process are analysed to identify opportunities for a more holistic understanding of sustainability that supports sustainable, reflexive FM practices beyond the instrumental implementation of management systems, certifications and KPIs.

\section{Capabilities for sustainable facilities management in Albertslund}

The action research process in Albertslund's Department of Public Property was initially aimed at transforming the department into a sustainable FM organisation, with an emphasis on understanding FM as a holistic approach to the development and operation of public property. Prior to commencing the research, two functions had been merged to create the department, and two distinctive cultures existed, represented by employees from the former operational function and those from a more strategic planning function.

Despite the documented high profile of environmental management in Albertslund, the employees reported that daily practice was not sustainable. The employees 
experienced a lack of effectiveness and knowledge sharing, fragmentary and random prioritisation, and significant frustration with the green branding of the organisation, which did not always reflect daily practice. At the managerial level, major challenges were confronted with respect to stress, long-term sick leave and employees leaving their positions for other jobs. This situation was occurring when the workshop-based action research process was initiated.

In the first two workshops, the focus was to identify what worked well in the organisation and what the employees should emphasise more. This step led to four suggestions for strengthening knowledge sharing and building a strategic approach to sustainability in FM:

(1) Strategy for sustainable FM (strategy and planning, common platform for planning, communication and priority of values).

(2) Data handling (organising, filing structure, common template, professional knowledge/FM, citizen service, GIS, coupling of data connected to locality and visualisation).

(3) Environmental management in practice (strategy for sustainable maintenance, practical environmental work, implementation of environmental goals, definition of sustainability and financial models).

(4) Communication, cooperation and dissemination (quality assurance of documentation and in administrative work, knowledge sharing, coordination and cooperation, social coherence in the department and sustainability at the strategic level).

The third workshop was organised as a future creation workshop to create an arena for critiquing common practice, which could be used as a driver to collectively formulate visions and specific actions. The critique phase added a new dimension to the collective description of work life in the department. Sources of frustration included the following:

- the organisation is too large and is functioning poorly;

- IT hardware and software are not up to date;

- there is no balance between ambitions and resources;

- time for planning is insufficient;

- there is a lack of knowledge of the environment in everyday decision-making; and

- work that occurs during transportation (train/bus) is not regarded as working hours.

The third step in the workshop process was to create utopias as future horizons to free employees' creativity and to facilitate a dialogue regarding employees' ideas for the future. At this stage, the following four utopias were discussed:

(1) Happy employees and management:

- The utopian work life is coherent and balanced. Team members prioritise tasks together with the manager. Members have influence over their own working conditions, and their tasks correspond to their resources.

(2) Project management in paradise:

- The ideal organisation is entirely project oriented, with employees working across administrative borders on projects and sharing a holistic view of the facilities that support the core business. 
(3) A coherent local society with common goals:

- In the utopian society, the local authority works together with citizens and businesses on an equal basis, aiming for coherence and mutual responsibility for "the good life".

(4) Greater cooperation between local authorities:

- The local authority works together with other local authorities on an administrative level to promote more effective and holistic management of real estate and services and to simultaneously promote a more exciting work life for skilled employees within the same profession who work for other authorities.

This highly condensed overview describes the development process in the local authority, which facilitated not only a collective understanding of the strengths and weaknesses in the employees' organisation but also a collective dialogue on how and why internal work processes should be developed.

The workshops provided a free arena in which employees could reflect on the role of sustainable FM and collectively build a shared understanding of the parameters defining their work and the space for action. The workshops provided the necessary distance from daily practice to identify solutions for more effective practice: better communication and the development of a real estate strategy, a maintenance plan for public buildings, a manual of procedures and a GIS-based database from which all relevant data connected to a specific facility could be drawn. All of these tools and focus areas would be used to enhance the holistic understanding of development and practice.

The FM organisation has the unique characteristic of being involved in almost every strategy and plan in the local authority because all services and all support for local society have a physical dimension connected to a built facility that is managed by the department. During the action research process, key employees reported in the semi-structured interviews that they became more competent partners in strategic cooperation as a result of new skills and understanding of processes. These skills are, according to Fournier, necessary for collaboration with other departments. An example from Albertslund is dialogue with the Department for Children and Youth. The development of schools and kindergartens on a holistic basis will need to account for pedagogical values, demographic development, building aesthetics, cultural and environmental values and transportation logistics.

At the close of the workshop process (Galamba, 2012), the joint evaluation (employees and facilitators) concluded: the process led not only to change in practices related to tools and plans but also to a shared understanding of sustainability and public governance that became the basis for each individual employee's personal conduct. Employee capabilities were strengthened in terms of employees' ability to navigate the cross-pressure between managerial criteria for legitimacy and criteria anchored in a broader and more contextual understanding of sustainability. The six statements of learning outcome are detailed below.

When the survey was conducted two years later, the effect was still significant. However, it was also clear that the ideas had not been implemented due to lack of priority. The survey showed a majority of participants believe the workshop process had "a significant long term effect" (6), while a minority believe the effect was only "short term" (2) or nonexistent (1). 
The survey confirms the action research was useful for building collective competences. The most important effects reported by respondents include:

(1) we got to know each other better and our internal social working climate improved (4);

(2) we became better at incorporating integrated and strategic thinking into our daily work (2);

(3) we developed a new understanding of how we as FM organisation can contribute to sustainable development at the societal level (2); and

(4) we improved our ability to translate tacit knowledge into explicit shared knowledge (1).

As facilitators, we also aimed to support planning, coordination and evaluation practices as elements of knowledge sharing and the holistic approach. At the end of the workshop process, these were also identified as positive outcomes. However, no survey respondents identified these effects as among the most important effects of the workshop process:

(5) we improved our ability to plan and coordinate our work (0); and

(6) we established the evaluation culture we have today (0).

The comments explain these outcomes. After the workshop process ended, the managerial focus on SFM faded and the employees drifted back to workdays with too many tasks and too little time. In addition, another reorganisation was implemented, and some staff were "lost" to another department. We therefore conclude that the workshop process facilitated the building of a collective understanding of holistic sustainable FM; however, project ideas and new practices were not implemented in full for several reasons. This result is common where change management processes are not properly maintained.

\section{Sustainable facilities management capability framework}

From the knowledge gained during the joint process (2008-2011), it is possible to characterise in general terms the basis for the improvements in the department's knowledge sharing, code of conduct and control of practice (Figure 4). This information qualifies and contextualises the model in Figure 3 that was derived from a theoretical body of knowledge.

Fournier claims that individual employees must translate politics and more or less explicit criteria of legitimacy into practice through control of their own practice and body of knowledge (Fournier, 1999). Through the study of the local FM organisation in Albertslund, we have gained a more nuanced understanding of the type of FM knowledge that is needed and different ways of strengthening control of one's own practice. Although the FM code of conduct never became explicit in the Albertslund process, knowledge sharing and an evaluation culture were mentioned as essential to the ability to learn from project to project.

The employees point to the need for FM knowledge, which should include not only FM know-how but also understanding of the concept of sustainability and technologies for sustainable development, as well as public governance technologies to work holistically and strategically with SFM. An example is a new kindergarten to passive 


\section{F}

$34,3 / 4$

190

Figure 4.

Framework for a sustainable FM code of conduct: translation occurs between policy and the personal conduct of the facilities manager through the articulation of the criteria of legitimacy

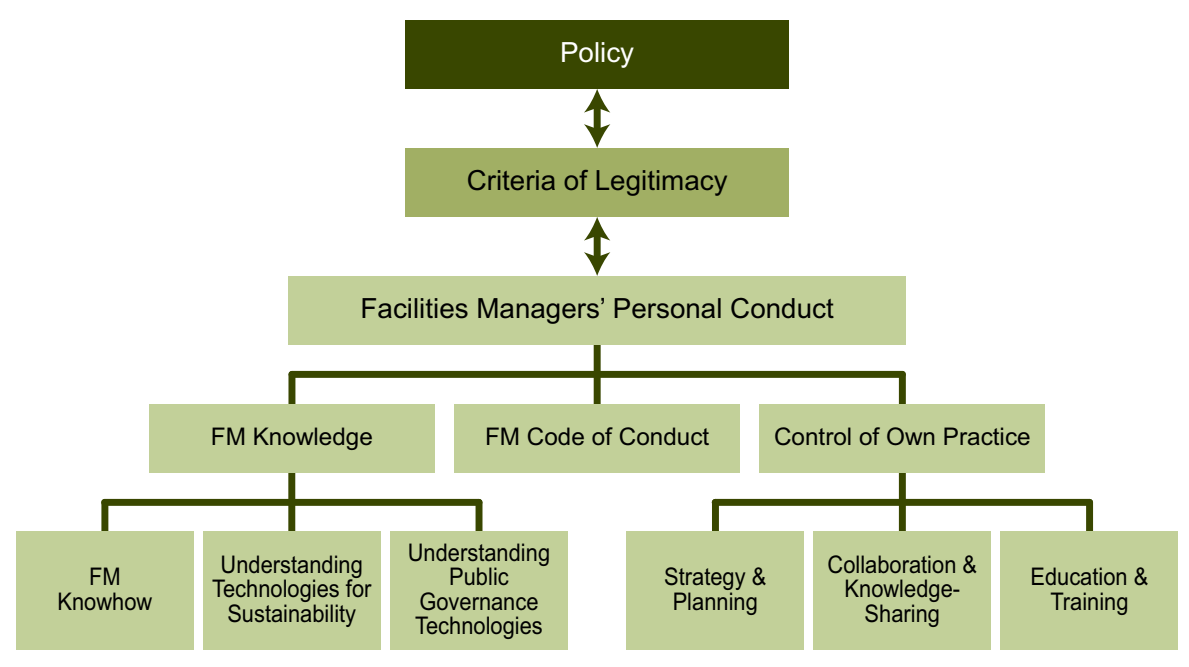

Notes: The conduct of the facilities manager working with sustainable facilities management is based on three types of knowledge: FM know-how, the substantial aspects of sustainability and technologies for sustainability, and an understanding of the mechanisms of public governance; control of one's own practice is strengthened by strategy and planning, cooperation and knowledge sharing, and education and training

house standard. The project team needs to know common construction and FM practices as well as understand the passive house concept and its technical implications. In addition, team members must understand local authorities' governance technologies, which establish the context for finances, decision-making structures and political ambitions among other factors.

Although it seems obvious that facilities' managers should have control of their own practices, this control was not reported when the action research process was initiated. Employees were unable to make long-term plans, and daily practice was determined by the most urgent tasks. The consequences were slow working procedures, uncoordinated initiatives, sub-optimisation and frustration among employees. When this practice was addressed from a work-life perspective, and current practices were analysed in view of the utopian future horizons for the sustainable work life held by the employees, the notion of a "free arena" emerged. Free arenas are spaces (times and places) where innovation can occur without being directed by specific goals and KPIs. Further, the action research pointed to ways of increasing control of own practice through explicit strategies and planning, collaboration and knowledge sharing and education and training.

\section{Discussion}

We suggest that individual and collective capabilities for sustainable FM practices must be purposively accumulated, which can be achieved through a workshop-based process in which employees construct common utopian horizons for a sustainable society and a culturally embedded FM code of conduct. 
The workshop process was an experiment in facilitating an organisation's collective reflections on the concept of sustainability and the concept's translation to the local organisational context and individual work. The strength of using the Department of Public Property in Albertslund as case organisation is the presence of significant work life experience with integration of sustainability in real estate management. This experience is due to the historical commitment to sustainability at the local political level and the pioneering role of local authorities in implementing sustainability tools. We argue that we are using the strongest example of SFM leadership ambition in a Danish context, and Albertslund's long-term commitment has also gained international recognition. The framework should therefore be regarded as a scholarly model for other local authorities with a similar dedication to building collective competences for strategic SFM and for demonstrating leadership in SFM. While other local authorities may not have advanced to the level of Albertslund, the framework can be a source of inspiration. A weakness of the study is its design as a single-case qualitative study, which can be criticised for its lack of statistical validity. Another issue is the existing working culture of organisations that might benefit from the workshop process. Organisations characterised by silo-thinking, control and bureaucracy may be too distant culturally from our suggested workshop approach. A final issue could be the lack of focus on the local/national economy and socially external factors that are important to how an organisation practices FM. This is issue not addressed directly and is instead assumed to be a factor in the relevant polities, which might be a limitation. This issue could be further studied through multiple case studies. Further testing and development of the framework is recommended, but was not possible within this project due to time and resource limitations.

In Albertslund, we pursued an open development process to build collective competences for SFM. Although the process was not focused on a specific output, the first department portfolio strategy was formulated within the process, and a Web page was established to share information and working procedures. We recognise that few other FM organisations will embark on an open process similar to that of Albertslund, but we expect that more focused processes will benefit from the capability framework to plan initiatives to strengthen strategic FM within the organisation. Subsequent to the research process, the workshop approach and the framework (Figure 3) were used on a commercial basis to formulate department development plans based on reflections on the status and visions of the future as well as in a collective process identifying development goals and actions.

Elmualim et al. (2010) note that a lack of support from senior management is a major barrier to SFM. The Albertslund process was not hampered by a lack of support from senior management, as sustainable development has been on the political agenda in Albertslund since the urban expansion in the 1970s through the era of Agenda 21 in the 1990s and now with political ambitions of contributing to a sustainable transition on the societal level. Other public authorities might be less experienced or might have a more narrow policy that legitimates only energy-saving activities, for example. We argue, however, that with time and with a narrower focus, the framework can facilitate a constructive process for identifying organisations' capabilities and development plans.

Baharum and Pitt (2009) also stress the importance of a strategy in their literature review of Green Intellectual Capital. They suggest a different framework where Green intellectual knowledge is a combination of green human, structural and consumer 
knowledge. For a public organisation led by politicians, the Fournier framework seemed to be a more appropriate theoretical framework for our deductive analysis of the Albertslund process. However, the need for reflective practitioners who are able to navigate a work life with contradictions and dilemmas and who can determine the appropriate course of action at the appropriate time is common to both studies. In contrast to Baharum and Pitt, we focus on a learning journey to build these capabilities though a managerial focus on utopian horizons and policy, criteria of legitimacy and personal code of conduct. We also specify various types of FM knowledge and ways of improving control of own practice.

The capability framework is relevant for FM professionals (including senior management of internal FM organisations, consultants and educators) who want to promote SFM from a strategic and proactive position based on a holistic understanding that is interconnected with reflective, sustainable FM practice. We refer to this SFM practice that goes beyond instrumental implementation of management systems, certifications and KPIs as the "second generation of sustainable FM". Employees in such an FM function must be considered key actors in confronting future sustainability challenges, and more work is necessary to further develop methods for employee empowerment. One such step could be to conduct a critical review of various strategies for sustainable FM as a means of facilitating change towards a reflective, sustainable FM practice in public organisations, including the development of legitimacy criteria connected to un-measurable aspects of sustainability.

\section{Conclusions}

The goal of this article was to show how an empowerment process facilitated largely through workshops can help FM employees to develop the collective capability to make a purposive impact on the sustainable development of local society. The process is based on a holistic understanding of SFM and anchored in an emerging "FM code of sustainable conduct".

We suggest a framework for an SFM code of conduct that ensures a broader understanding of sustainability than that represented, for example, by the environmental management system because it is necessary to guide action in daily practice. The framework embraces the FM organisation's need to navigate a complex work life filled with strategic contradictions, dilemmas and incomplete information; it incorporates capabilities for translation among policies, legitimacy criteria and personal codes of conduct. With the case of Albertslund, we have demonstrated that this understanding can be developed through a workshop process and can include dialogues of common utopian horizons for a sustainable society. Coupled with perspectives of sustainability on a societal level and public governance, tools for sustainability can then be critically evaluated and adjusted to better support sustainable practice.

In addition, this article shows how a process aimed at promoting a holistic, sustainable practice also resulted in a process of empowerment in which employees shifted from operating at a reactive and primarily tactical level to adopting a proactive strategic position in which translation among politics, strategy, tactics and daily practice became the basis for prioritisation and decision-making. From a position in which green accounting and a certified environmental management system were the main guidelines for action for decades, the conclusions of our work point to the second generation of SFM: a reflective sustainable practice based on a culturally embedded 
understanding of sustainability that reaches towards a societal perspective and embraces social, environmental and economic aspects as an integrated whole.

\section{References}

Baharum, M.R. and Pitt, M. (2009), "Determining a conceptual framework for green FM intellectual capital", Iournal of Facilities Management, Vol. 7 No. 4, pp. 267-282.

Beck, U. (1996), "Risk society and the provident state", in Lash, S., Szerszynski, B. and Wynne, B. (Eds), Theory, Culture \& Society, Sage, London, pp. 27-44.

Brignall, S. and Modell, S. (2000), "An institutional perspective on performance measurement and management in the "new public sector", Management Accounting Research, Vol. 11 No. 3, pp. 281-306.

Cooperrider, D.L. and Srivastva, S. (1987), "Appreciative inquiry in organizational life”, in Pasmore, W.A. and Woodman, R.W. (Eds), Research in Organizational Change and Development, JAI Press, Greenwich, CT, Vol. 1, pp. 129-169.

Dean, M. (1999), Governmentality - Power and Rule in Modern Society, Sage, London.

Dubrovsky, V. (2004), "Toward system principles: general system theory and the alternative approach”, Svstems Research and Behavioral Science, Vol. 21 No. 2, pp. 109-122.

Due, P.H. (2007), Mere for pengene ved strategisk nytcenkning af den kommunale ejendomsdrift, Dansk Facilities Management Netværk and Boligfonden Kuben, Copenhagen.

Elling, B. (2010), "Modernity and rationality", in Nielsen, K.A., Elling, B., Figueroa, M. and Jelsøe, E. (Eds), A New Agenda for Sustainability, Ashgate, Farnham, pp. 31-43.

Elmualim, A., Shockley, D., Valle, R., Ludlow, G. and Shah, S. (2010), "Barriers and commitment of facilities management profession to the sustainability agenda", Building and Environment, Vol. 45 No. 1, pp. 58-64.

Fennimore, J.P. (2013), Sustainable Facility Management: Operational Strategies for Today, Pearson, Upper Saddle River, NJ.

Flood, R.L. (2006), “The relationship of 'systems thinking' to action research”, in Reason, P. and Bradbury, H. (Eds), Handbook of Action Research: The Concise Paperback Edition, Sage, London, p. 362.

Flood, R.L. (2010), "The relationship of systems thinking to action research", Sustemic Practice and Action Research, Vol. 23 No. 4, pp. 269-284.

Fournier, V. (1999), “The appeal to 'professionalism' as a disciplinary mechanism”, Sociological Review, Vol. 47 No. 2, pp. 199-401.

Fournier, V. (2008), "Escaping from the economy: the politics of degrowth", International Iournal of Sociologv and Social Policv. Barmarick Publications, Vol. 28 Nos 11/12, pp. 528-545.

Galamba, K.R. (2011a), Public Facilities Management and Action Research for Sustainability, Technical University of Denmark, Copenhagen.

Galamba, K.R. (2011b), “A critical review of the environmental management system as a tool for sustainability", in Jensen, P.A. and Nielsen, S.B. (Eds), Facilities Management Research in the Nordic Countries: Past, Present and Future, Polyteknisk Forlag, Lyngby, pp. 133-143.

Galamba, K.R. (2012), "Public facilities management and action research for sustainability”, PhD Thesis, Department of Management Engineering, Technical University of Denmark, Copenhagen.

Grimshaw, B. (2001), "Ethical issues and agendas”, Facilities, Vol. 19 No. 1, pp. 43-51.

Hawken, P., Lovins, A.B. and Lovins, L.H. (2010), Natural Capitalism: The Next Industrial Revolution, Earthscan, London, Vol. 10. 
Holm, J. (2007), "Eksperimenter i lokalsamfundets miljøomstilling: 12 års Lokal Agenda 21-arbejde i Danmark", in Holm, J., Petersen, L.K., Remmen, A. and Hansen, C.J. (Eds), Økologisk Modernisering på dansk - Brud og Bevagelse i Miljøindsatsen, Frydenlund, Copenhagen, Vol. 1, pp. 151-187.

Hood, C. and Peters, G. (2004), "The middle aging of new public management: into the age of paradox?", Iournal of Public Administration Research and Theorv, Vol. 14 No. 3, pp. 267-282.

Hvid, H. (2006), Arbejde og Bceredygtighed. Frydenlund, Copenhagen.

IPPC (2013), Climate Change 2013: The Physical Science Basis, IPPC, Geneva.

Jensen, P.A. (2011), Håndbog i Facilities Management, Dansk Facilities Management Netværk, Copenhagen, Vol. 3.

Jensen, P.A. and Due, P.H. (2008), "Organisation of facilities management in municipalities", Healthy and Creative Facilities: CIB W070 Conference in Facilities Management, Edinburgh, pp. 395-402.

Jensen, P.A. and Malmstrøm, O.E. (2012), "The start of a Nordic focus on the added value of FM", in Jensen, P.A., van der Voordt, T. and Coenen, C. (Eds), The Added Value of Faclities Management: Concepts, Findings and Perspectives, Polyteknisk Forlag, Lyngby, pp. 31-43.

Junghans, A. (2013), "Decision support model for energy-efficient improvement of entire building stocks”, Facilities, Vol. 31 No. 3, pp. 173-184.

Lerborg, L. (2010), Styringsparadigmer $i$ den Offentlige Sektor. Styringsparadigmer $i$ den Offentlige Sektor, Jurist-og Økonomforbundet, Copenhagen.

Love, P. and Bullen, P.A. (2009), "Toward the sustainable adaptation of existing facilities", Facilities, Vol. 27 Nos 9/10, pp. 357-367.

Lovins, A.B., Lovins, L.H. and Hawken, P. (2007), “A road map for natural capitalism”, Harvard Business Review, Vol. 85 No. 7, pp. 172-183.

Mol, A.P.J. (1996), "Ecological modernisation and institutional reflexivity: environmental reform in the late modern age", Environmental Politics, Vol. 5 No. 2, pp. 302-323.

Nielsen, B.S. and Nielsen, K.A. (2006), En menneskelig Natur: Aktionsforskning for Baredugtighed og Politisk Kultur, Frydenlund, Copenhagen.

Nielsen, K.A., Drewes, L., Munk-Madsen, E. and Hartmann-Pedersen, K. (2007), "When innovation, change and flexibility becomes the problem: sustainability through social research and through action research", The Action Research Conference, Oslo.

Nielsen, S.B. (2011), "Claims of sustainable FM: exploring current practices”, in Jensen, P.A. and Nielsen, S.B. (Eds), Facilities Management Research in the Nordic Countries: Past, Present and Future, Polyteknisk Forlag, Copenhagen, pp. 121-132.

Nielsen, S.B. and Galamba, K.R. (2010), "Facilities management - when sustainable development is core business", 9th EuroFM Research Symposium, EFMC 2010, Madrid.

Price, S., Pitt, M. and Tucker, M. (2011), "Implications of a sustainability policy for facilities management organisations”, Facilities, Vol. 29 Nos 9/10, pp. 391-410.

Sachs, W. (2007), "Fair future: resource conflicts, security and global justice: a report of the Wuppertal institute for climate, environmentt and energy”, Wuppertal Institut für Klima, Umwelt und Energie, London.

Saunders, M., Lewis, P. and Thornhill, A. (2012), Research Methods for Business Students, 6th ed., Pearson Education Limited, Essex. 
Sennett, R. (1999), Det fleksible Menneske Eller Arbejdets Forvandling og personlighedens Nedsmeltning, Hovedland, Højbjerg.

Shiva, V. (2005), Earth democracy: Justice, Sustainability, and Peace, South End Press, Cambridge, MA.

Svensson, L. and Nielsen, K.A. (2006), Action Research and Interactive Research: Beyond Practice and Theory, Shaker Publishing, Maastricht.

Tay, L. and Ooi, J.T.L. (2001), “Facilities management: a 'Jack of all trades'?”, Facilities, Vol. 19 No. 10 , pp. 357-363.

United Nations. (1987), Report of the World Commission on Environment and Development: Our Common Future, United Nations, New York, NY.

United Nations Department of Public Information (1993), Agenda 21: Programme of Action for Sustainable Development: Rio Declaration on Environment and Development: Statement of Forest Principles: the Final Text of Agreements Negotiated by Governments at the United Nations Conference on Environment and Development (UNCED), United Nations, Geneva.

Wiggins, J.M. (2010), Facilities Manager's Desk Reference, Wiley-Blackwell, Oxford.

\title{
Further reading
}

Häkkinen, T. and Nuutinen, M. (2007), "Seeking sustainable solutions for office buildings", Facilities Vol. 25 Nos 11/12, pp. 437-451.

\begin{abstract}
About the authors
Kirsten Ramskov Galamba is Biologist of education and completed her $\mathrm{PhD}$ in public facilities management and action research for sustainability in 2012 at Centre for Facilities Management at the Technical University of Denmark. She is now working at The Capital Region of Denmark with Regional Development in the Unit for Climate and Resources.

Susanne Balslev Nielsen is Associate Professor and Deputy in Centre for Facilities Management and has since 2004 specialised in sustainable facilities management. Sustainable development in the built environment is the core of her research and teaching, since graduation as civil engineer in 1994. Susanne Balslev Nielsen is the corresponding author and can be contacted at: sbni@dtu.dk
\end{abstract}

For instructions on how to order reprints of this article, please visit our website:

www.emeraldgrouppublishing.com/licensing/reprints.htm

Or contact us for further details: permissions@emeraldinsight.com 